\title{
Habitats and Foraging Movements of Larvae of Molanna uniophila Vorhies (Trichoptera: Molannidae) in Pratt Lake, Michigan, USA
}

\author{
Neal D. Mundahl ${ }^{1}$ and Erik D. Mundahl ${ }^{2}$ \\ ${ }^{1}$ Center for Ecology \& Environmental Science, Department of Biology, Winona State University, Winona, MN 55987, USA \\ ${ }^{2}$ Travis/Peterson Environmental Consulting, Inc., 3305 Arctic Boulevard, Suite 102, Anchorage, AK 99503, USA
}

Correspondence should be addressed to Neal D. Mundahl; nmundahl@winona.edu

Received 26 August 2015; Revised 5 December 2015; Accepted 10 December 2015

Academic Editor: Rostislav Zemek

Copyright (C) 2015 N. D. Mundahl and E. D. Mundahl. This is an open access article distributed under the Creative Commons Attribution License, which permits unrestricted use, distribution, and reproduction in any medium, provided the original work is properly cited.

\begin{abstract}
Habitats and foraging movements of larvae of Molanna uniophila Vorhies (Trichoptera: Molannidae) were studied during four summers in Pratt Lake, Michigan. Larvae lived and fed in shallow $(<10 \mathrm{~cm})$, sand-bottomed lake margins, where macrophyte densities ranged from 86 to $452 \mathrm{stems} / \mathrm{m}^{2}$. Average densities of larvae varied fivefold between years $\left(2.7\right.$ versus 13.6 individuals $\left./ \mathrm{m}^{2}\right)$, but larval densities did not vary significantly between habitat patches with low $\left(120 \mathrm{stems} / \mathrm{m}^{2}\right)$ and high $\left(360 \mathrm{stems} / \mathrm{m}^{2}\right) \mathrm{macrophyte}$ densities. Larvae and their cases exhibited strong patterns of simple, linear growth. Diets of larvae were dominated by amorphous detritus, plant debris, diatoms, and filamentous algae, but midges, cladocerans, and other microscopic aquatic animals also were consumed. Larvae shifted their bodies and cases forward across the surface sediments up to 4 times/minute while foraging, moving as much as $2.5 \mathrm{~m}$ /hour. Movements and distances traveled while feeding increased significantly with increased water temperatures, peaking during midafternoon hours. Distances moved by feeding larvae did not differ between habitats with low versus high macrophyte densities. Larvae foraged most actively during daylight hours and did not selectively utilize macrophyte beds as partial refugia from potential predators while feeding.
\end{abstract}

\section{Introduction}

Aquatic insect larvae use a variety of strategies to acquire their nutrients, from grazing algae and shredding plants, to consuming animal prey entirely or in part, to collecting or gathering dispersed and/or suspended organic matter [1]. Food resources often are patchily distributed within aquatic habitats, requiring larvae to balance searching and consuming to maximize energy intake over time [2,3]. Feeding movements of larval insects within and among food patches often conform to the predictions of optimum foraging theory $[2,4,5]$.

While feeding, many aquatic insect larvae may expose themselves to the risk of predation. Low risk of predation may not alter a larva's foraging behavior, but higher risk can suppress foraging activities and/or switch them to time periods with lower risks [6, 7]. Balancing foraging and predator avoidance can have significant effects on a species' life history, from reducing growth rates and delaying adult emergence to selecting for different genetic ecotypes in habitats that differ in predation risk $[7,8]$.

Caddisflies (Insecta: Trichoptera) are common components of most aquatic communities, with species-rich assemblages of caddisflies often suggestive of good water quality [9]. Larval caddisflies display all types of feeding strategies, with grazers, shredders, and collector/gatherers particularly well represented in most aquatic communities [1]. Caddisfly larvae construct cases using excreted silk to bind together organic or inorganic materials gathered from the local environment, providing both camouflage and protection from predators [1, 10]. These cases may modify the responses of caddisfly larvae to potential predators, allowing them to forage while hidden or protected from predation [10-12]. These same cases also may help caddisfly larvae to better 
maintain position while foraging, serving as ballast against currents or wave action $[4,5,10,11]$.

Many studies of foraging by aquatic invertebrates have focused on grazers (e.g., [2, 3, 13]) and shredders (e.g., [14-16]) in lotic habitats. However, field studies on collector/gatherers are much less common (e.g., $[17,18])$, especially in lentic environments. Consequently, the objectives of our study were to examine the habitats and foraging movements of collector/gatherer caddisfly larvae in the nearshore zone of a lake in the Midwestern USA. Specifically, we gathered basic information on diets, body and case morphometry, habitats, and densities of larvae of the gray checkered sedge, Molanna uniophila Vorhies (Trichoptera: Molannidae), in Pratt Lake, Michigan, USA.

Molanna uniophila is a mobile, omnivorous caddisfly that inhabits sandy lake shorelines and rivers in Midwestern and eastern North America, especially in areas surrounding the Great Lakes $[10,19]$. The species is univoltine, with adults emerging from mid-May through September [20]. Molanna larvae construct tapering, tubular cases of sand and gravel held together with silk [21]. These tubular cases also have prominent lateral flanges and an anterior hood that completely covers the larva [11]. Compared to most other Molanna species, M. uniophila larvae distinctively incorporate larger sand and gravel particles into the lateral flanges of their cases $[22,23]$.

Molanna uniophila larvae forage as they move across preferred sand substrate, consuming an omnivorous diet of diatoms, algae, plant matter, and small insects and microcrustaceans $[22,23]$. Although they can occur at water depths $>5 \mathrm{~m}$, most larvae occur in water $<1 \mathrm{~m}$ deep on wave-swept sand bottoms with little or no vegetation [23, 24]. When foraging, larvae move across the lake bottom by raising up the anterior end of the body with their thoracic legs and either dragging their case forward or pivoting sideways on their anal prolegs and claws (N. Mundahl, personal observation). Foraging larvae produce trails caused by dragging the posterior ends of their cases through the fine lake-bottom sediments.

In our study, we tested two hypotheses about the foraging movements of $M$. uniophila larvae: (1) that their foraging would be affected by macrophyte density in nearshore habitats and (2) that foraging movements would occur during daylight hours and be correlated with changing water temperatures. We anticipated that Molanna larvae would use macrophyte beds as protected foraging sites but that their feeding movements would be compromised by the presence of macrophyte stems. Furthermore, we expected that their protective cases would allow Molanna larvae to forage during the day, when warmer water temperatures would allow for more rapid and extensive foraging movements.

\section{Materials and Methods}

2.1. Study Site. The study was conducted during summers of 1995 and 1997-1999 at Pratt Lake, Gladwin County, MI, USA $\left(44^{\circ} 01^{\prime} 28.78^{\prime \prime} \mathrm{N} 84^{\circ} 32^{\prime} 53.37^{\prime \prime} \mathrm{W}\right)$. Pratt Lake is a 73 ha seepage lake lying within the West Branch Glacial Moraine in central Michigan. It has a maximum depth of $8.5 \mathrm{~m}$, with clay and peat sediments dominating deeper portions and sand and gravel most common in nearshore habitats. Clear water and shallow depths allow for growth of extensive macrophyte beds throughout the littoral zone. Native macrophytes included muskgrass (Chara spp.), various pondweeds (Potamogeton spp.), wild celery (Vallisneria americana), and water stargrass (Zosterella dubia), whereas Eurasian watermilfoil (Myriophyllum spicatum) was the most common nonnative macrophyte in the system. The study site was located along the southern shore, in an area dominated by sand substrates, Chara, and Potamogeton.

2.2. Macrophyte Densities, Larva Densities, and Habitat Use. We measured macrophyte densities throughout the study site in 1995 (Figure 1(a)). Because densities appeared to differ dramatically between two subsections of the study area, we made stem counts in five $0.1 \mathrm{~m}^{2}$ plots within each of what we hereafter refer to as high-density and low-density subsections. Abundances of individual species were not determined, but common species were noted.

During 1995 and 1999, we determined densities of Molanna larvae in $1 \mathrm{~m}^{2}$ plots throughout the study site (Figure 1(a)). In 1995, we counted larvae in 18 plots, with plots divided equally between high-density and low-density macrophyte beds. In 1999, we made counts of larvae in nine plots distributed randomly throughout the study site.

We measured the water depths occupied by sedge larvae during three different years (Figure 1(a)). In 1995, we measured water depths of larvae in plots divided equally between high-density and low-density macrophyte beds. In 1997 and 1998, we measured water depths used by Molanna larvae throughout the study site, regardless of macrophyte densities.

2.3. Larva Collection, Measurements, and Diet. We collected a small number $(n=13)$ of Molanna larvae with their cases from the Pratt Lake study site in 1997 for morphometry and diet assessments (Figure 1(b)). Collection took place during late afternoon (at 16:00 local time). Six larvae were preserved in $70 \%$ ethanol along with their cases for use in diet analysis. The remaining seven larvae were carefully removed from their cases, with cases preserved in ethanol and larvae returned to the lake. Larvae can reconstruct a complete case in 12 to 18 hours [21]. We retained cases for morphometry measurements.

In the laboratory, we removed preserved sedge larvae from their cases and measured total larva length and head capsule width to the nearest $0.05 \mathrm{~mm}$ with dial calipers. After blotting with a paper towel to remove moisture, we weighed larvae to the nearest $0.1 \mathrm{mg}$ with an analytical balance.

We made a series of measurements on each case, including total length (anterior-posterior), maximum width (side to side), and thickness (dorsal to ventral) at the anterior opening, all to the nearest $0.05 \mathrm{~mm}$ using dial calipers. We also air-dried each case and weighed it to the nearest $0.1 \mathrm{mg}$ with an analytical balance.

Diets of Molanna larvae were examined in the laboratory by removing, identifying, and counting organisms and materials contained in foreguts of six larvae. Foreguts were 


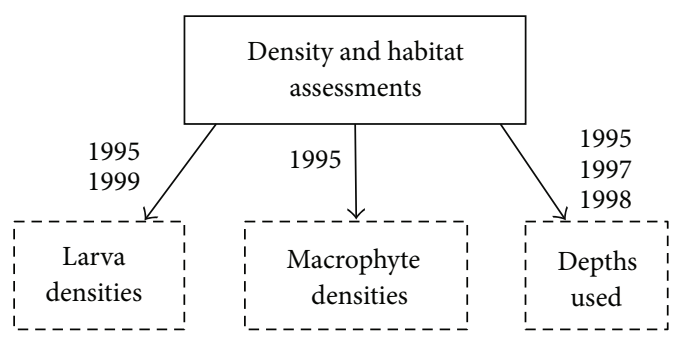

(a)

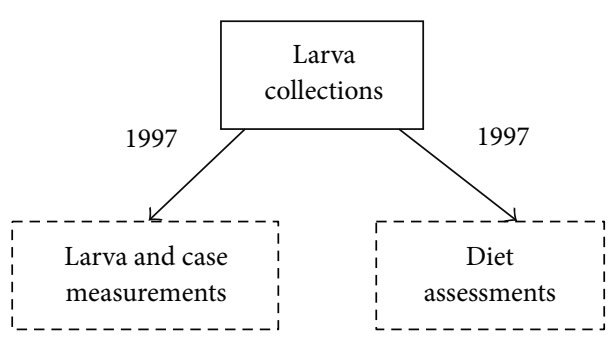

(b)

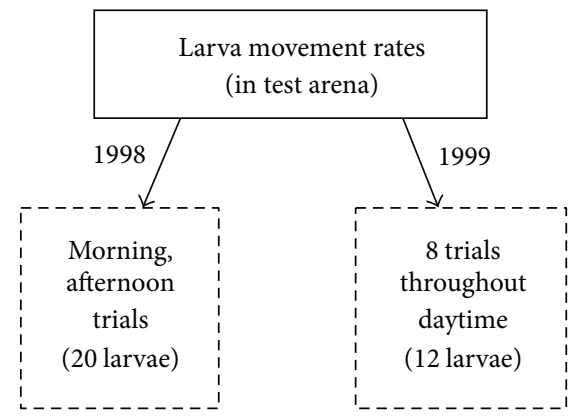

(c)

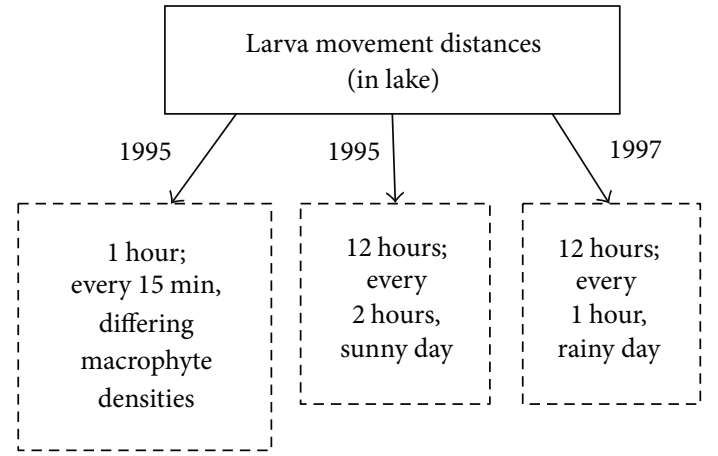

(d)

Figure 1: Diagrammatic representation of the methods used to study Molanna uniophila in Pratt Lake, Michigan, USA: (a) assessments of larva densities and habitats, (b) collections of larvae for measurement and diet analyses, (c) movement rates of larvae in test arena trials, and (d) distances moved by larvae during in lake trials.

removed by grasping both ends of a larva with forceps and pulling the head and attached foregut free from the body. We slit open the foregut and flushed its contents into a $1 \mathrm{~mL}$ Sedgwick-Rafter counting cell. Diet materials were viewed separately for each larva under a compound microscope at 100x magnification. We counted and identified ingested foods in each of the five separate fields of view and combined them to represent the diet of each larva. No attempt was made to estimate area or volume of ingested food items.

2.4. Movement Rates. We used a circular $0.25 \mathrm{~m}^{2}$ test arena to examine the rate of movements of Molanna larvae during 1998 and 1999 (Figure 1(c)). We covered the bottom of the arena with a $1 \mathrm{~cm}$ thick layer of sand and organic sediments skimmed from the surface of the study site. No living macrophytes were included within the test arena. Sediments were covered with lake water to a depth of $3 \mathrm{~cm}$, and the arena was positioned at the shoreline during testing.

Either 12 or 20 late instar (large) Molanna larvae were evenly distributed throughout the test arena in a grid pattern during movement trials. Although this arrangement resulted in a density of larvae two to three times greater than the maximum observed within the lake (see Section 3), this procedure allowed us to simultaneously monitor multiple larvae without larvae contacting one another during a trial. Larvae within the arena were observed for 10 minutes and movements were tallied separately for each larva. We converted the 10minute tallies to movements/minute for each larva. Water temperature was measured during each trial with a digital thermometer.

During 1998, we conducted two movement trials, one during the morning (10:30) and another during afternoon (15:30; Figure 1(c)). No nighttime studies were undertaken, as preliminary examinations of marked larvae indicated that they did not move at night, aside from slightly burying the edges of their cases into the surface sediments. We collected 20 larvae from the lake and placed them within the test arena 1 hour prior to beginning observations. Movements (forward advances and pivots on the posterior end) were recorded for each individual. After testing, Molanna larvae were returned to the lake.

During 1999, we conducted eight movement trials, one every two hours from 07:00 to 21:00 (Figure 1(c)). We collected 12 larvae from the lake and placed them within the test arena 1 hour prior to beginning observations. Movements were observed and recorded as described above. Unlike previous trials, the same larvae were used for all eight trials, remaining undisturbed in the test arena between trials. Because larvae were not uniquely marked and continued moving during nonobservation periods, we could not associate movements of individual Molanna larvae across the various trials.

2.5. Movement Distances. We examined distances traveled by the feeding movements of Molanna larvae in Pratt Lake during 1995 and 1997 by conducting three types of trials 
(Figure 1(d)): (1) short duration (1 hour, assessed every $15 \mathrm{~min}$ ) in both high-density and low-density macrophyte beds, (2) long duration (12 hours) assessed every 2 hours for 30-minute periods, and (3) long duration (12 hours) assessed every hour (i.e., continuous monitoring). In all trials, we marked initial locations of free-ranging larvae in the lake by inserting a small stick in the lake bottom at the posterior end of the larval case. After each time period ( $15 \mathrm{~min}, 30 \mathrm{~min}$, or $1 \mathrm{~h}$, depending on trial), the straight-line distance between the marker stick and the posterior end of the larva in its new location was measured with a ruler. The marker stick was then repositioned to begin the next observation period. Feeding Molanna larvae left trails in the lake sediments by dragging their cases, so tracking larvae from their starting points to their new locations was easy. However, these trails seldom followed a straight line across the lake bottom. Rather than attempting to measure the true lengths of these often-complex, curvilinear trails, we opted for the simple straight-line, before-after measurement. Consequently, our measurements of distances traveled by feeding sedge larvae should be considered as conservative.

In Trial 1, we marked locations of 24 Molanna larvae in Pratt Lake at 13:30, with 12 larvae in each of the highdensity and low-density macrophyte areas within the study site. We chose larvae spaced at least $50 \mathrm{~cm}$ apart to simplify monitoring. Every $15 \mathrm{~min}$ for $1 \mathrm{~h}$, we measured the distances traveled by all larvae, repositioning marker sticks after each measurement.

For Trial 2, we selected and marked locations of eight Molanna larvae within the study area (without regard to macrophyte densities) and measured their distances moved (as described above) during 30 min periods every two hours for 12 hours, from 08:00 to 20:00. Lake water temperatures were measured and recorded during each monitoring interval.

To begin Trial 3, we selected and marked locations of 20 Molanna larvae within the study area (without regard to macrophyte densities) and then measured their distances moved during $1 \mathrm{~h}$ periods every hour for 12 hours, from 07:30 to 19:30. Lake water temperatures were recorded every hour. To assess the potential effects of lake water temperature on distances moved by sedge larvae during feeding, we combined movement distance and water temperature data from Trials 2 and 3.

2.6. Data Analyses. We used a variety of statistical tests to analyze the data on Molanna larvae in Pratt Lake. Most tests were conducted using VassarStats (http://vassarstats.net). All two-sample comparisons were made with Student's $t$-test, with corrections made when sample variances were unequal. Multiple sample comparisons were made with single-factor analysis of variance (ANOVA) and post hoc Tukey's honest significant difference (HSD) tests. In instances where the independence assumptions for ANOVA could not be met, Kruskall-Wallis tests were used. Levene's $F$ tests were used for multiple comparisons of coefficients of variation. We used various regression models (linear, logistic, and exponential) to explore potential relationships between different dependent and independent variables.
TABLE 1: Measurements of larvae and cases of Molanna uniophila collected from Pratt Lake, Michigan, USA, in July 1997.

\begin{tabular}{lcc}
\hline & Mean \pm SD & Range \\
\hline Larvae $(n=6)$ & & \\
Total length $(\mathrm{mm})$ & $14.36 \pm 1.99$ & $12.50-17.65$ \\
Wet weight $(\mathrm{mg})$ & $31.8 \pm 18.3$ & $11.2-63.3$ \\
Head capsule width $(\mathrm{mm})$ & $1.37 \pm 0.17$ & $1.25-1.70$ \\
Cases $(n=13)$ & & \\
Total length $(\mathrm{mm})$ & $20.96 \pm 5.45$ & $14.70-31.50$ \\
Dry weight $(\mathrm{mg})$ & $419.7 \pm 215.6$ & $191.7-821.1$ \\
Maximum width $(\mathrm{mm})$ & $10.10 \pm 1.71$ & $7.55-13.00$ \\
Height at anterior opening $(\mathrm{mm})$ & $2.84 \pm 0.55$ & $2.15-4.00$ \\
\hline
\end{tabular}

\section{Results}

3.1. Habitat and Densities of Larvae. Macrophyte densities in the Pratt Lake study site varied fivefold among plots sampled ( 86 to $452 \mathrm{stems} / \mathrm{m}^{2}$ ), but the study site was fairly equally divided in area between high-density (mean \pm SD; $359 \pm 62$ stems $\left./ \mathrm{m}^{2}\right)$ and low-density $\left(123 \pm 35 \mathrm{stems} / \mathrm{m}^{2}\right)$ macrophyte beds. Chara was the dominant plant in lowdensity areas, whereas Chara and various Potamogeton spp. were common in high-density areas. Stem densities were significantly different $(t=7.45, \mathrm{df}=8, P<0.001)$ between these two portions of the study site.

Densities of Molanna larvae were highly variable during the study period. In 1995, densities ranged from 0 to 7 larvae $/ \mathrm{m}^{2}$, but densities were not significantly different $(t=$ 0.32 , $\mathrm{df}=16, P=0.753$ ) between high- and low-density macrophyte beds. Overall, Molanna larvae averaged $2.7 \pm 2.2$ individuals $/ \mathrm{m}^{2}$ in 1995. During 1999, densities of Molanna larvae averaged $13.6 \pm 9.5$ individuals $/ \mathrm{m}^{2}$, with a maximum density of 28 larvae $/ \mathrm{m}^{2}$. Densities observed in 1999 were significantly higher $(t=4.7, \mathrm{df}=25, P<0.0001)$ than those in 1995, possibly the result of changing water levels in the lake following replacement of an old water control structure.

Across all years of the study, Molanna larvae were found at water depths ranging from 4 to $35.5 \mathrm{~cm}$. Depths used by Molanna larvae averaged $<10 \mathrm{~cm}$ during 1995 (mean \pm SD: 7.7 $\pm 3.5 \mathrm{~cm})$ and $1998(9.6 \pm 2.8 \mathrm{~cm})$, but larvae were located in significantly (ANOVA $F_{2,131}=51.93, P<0.0001$ ) deeper water $(16.6 \pm 6.3 \mathrm{~cm})$ during 1997 (changing lake levels due to control structure changes). During 1995, depths used by Molanna larvae did not differ significantly $(t=1.21, \mathrm{df}=22$, $P=0.239)$ between high- and low-density macrophyte beds.

3.2. Morphometry of Larvae and Their Cases. Larvae collected from Pratt Lake averaged $>14 \mathrm{~mm}$ long and $>31 \mathrm{mg}$ wet weight (Table 1). As expected, weights of larvae were significantly (Levene's $F_{2,15}=5.54, P=0.0158$ ) more variable (coefficient of variation $(\mathrm{CV})=57.5 \%$ ) than were length and width measures (both CVs $<14 \%$ ). Size variations indicated that larvae represented two instars.

Cases of Molanna larvae were nearly 50\% longer than larvae but averaged 13 times heavier than the larvae that constructed and occupied them (Table 1). Cases displayed 
TABLE 2: Regression and correlation statistics for larvae and cases of Molanna uniophila collected from Pratt Lake, Michigan, USA, in July 1997. See Table 1 for measurement units.

\begin{tabular}{|c|c|c|c|c|}
\hline Variables $(X, Y)$ & Slope & $Y$ intercept & $P$ & $r^{2}$ \\
\hline \multicolumn{5}{|l|}{ Larvae } \\
\hline Length versus wet weight & 8.4675 & -89.7332 & 0.009 & 0.849 \\
\hline Length versus head capsule width & 0.0779 & +0.2477 & 0.014 & 0.814 \\
\hline \multicolumn{5}{|l|}{ Cases } \\
\hline Length versus dry weight & 38.9582 & -396.7661 & $<0.0001$ & 0.970 \\
\hline Length versus maximum width & 0.2769 & +4.2969 & $<0.0001$ & 0.776 \\
\hline Length versus height & 0.0860 & +1.0398 & 0.0002 & 0.725 \\
\hline \multicolumn{5}{|l|}{ Combined } \\
\hline Larva length versus case length & 1.9360 & -4.5221 & 0.0013 & 0.943 \\
\hline
\end{tabular}

variability similar in magnitude to larvae, with weights significantly (Levene's $F_{3,48}=7.30, P=0.0004$ ) more variable $(\mathrm{CV}=51.4)$ than linear measures (all CVs $<26 \%)$.

All morphometric, measure-versus-measure comparisons of Molanna larvae and cases were best described by simple linear models rather than logistic or exponential forms (Table 2). Wet weights and head capsule widths of larvae both were significantly correlated to length, and case length likewise was significantly correlated to other case measures. As expected, length of larvae also was strongly correlated to case length.

3.3. Diets. Larvae from Pratt Lake consumed nine different types of food items (Table 3). Plant-based foods, including diatoms, filamentous algae, and macrophyte fragments, together represented over half of the 457 items counted. In contrast, animal-based foods (e.g., midges, cladocerans, and rotifers) comprised only $7 \%$ of the diet items counted. However, the single, most common diet item overall was amorphous detritus, representing $>40 \%$ of all food items observed.

3.4. Movement Rates. During initial feeding movement trials, individual Molanna larvae moved from 0 to 27 times during $10 \mathrm{~min}$ observation periods. Only $5 \%$ of larvae failed to move during these observations, and these occurred only during the morning trial. Overall, larvae generally moved approximately once per minute. Larvae observed during the afternoon moved significantly $(t=2.21$, df $=32.4$ (adjusted for unequal sample variances), $P=0.034$ ) more often than did those during the morning (morning: $0.7 \pm 0.4$ movements/min; afternoon: $1.1 \pm 0.7$ movements $/ \mathrm{min}$ ).

Larvae changed their rate of movements during feeding trials that spanned the 14-hour period of daylight (Figure 2). Movement rates were low $(1 / \mathrm{min}$ or lower) during morning and late evening, when $>30 \%$ of larvae failed to move. However, movement rates were two to three times higher from late morning through early evening. The highest movement rates were observed in two larvae that averaged $>4$ movements/min during the $1300 \mathrm{~h}$ trial. Movement rates differed significantly (Kruskal-Wallis $H=62.26$, $\mathrm{df}=7$, $P<0.0001)$ among the eight trials, peaking during afternoon hours.
TABle 3: Diets of Molanna uniophila larvae $(n=6)$ collected from Pratt Lake, Michigan, USA, in July 1997. Values are means \pm SD of total counts of diet items from five random microscopic fields of view for each larva. Total diet items $=457$.

\begin{tabular}{lcc}
\hline Diet item & Number & Percent of total items \\
\hline Plant matter & & \\
$\quad$ Macrophyte fragments & $9.7 \pm 7.7$ & 12.7 \\
Filamentous algae & $11.5 \pm 12.1$ & 15.1 \\
$\quad$ Diatoms & $18.7 \pm 15.1$ & 24.5 \\
Animals & & \\
$\quad$ Cladocerans & $1.5 \pm 1.5$ & 2.0 \\
Midge larvae & $3.3 \pm 4.7$ & 4.4 \\
Midge adults & $0.2 \pm 0.4$ & 0.2 \\
Unidentified fly larvae & $0.2 \pm 0.4$ & 0.2 \\
$\quad$ Rotifers & $0.3 \pm 0.8$ & 0.4 \\
Unknown & & \\
$\quad$ Amorphous detritus & $30.8 \pm 27.9$ & 40.5 \\
\hline
\end{tabular}

Feeding movement rates of Molanna larvae in Pratt Lake were significantly correlated (movements $/ \mathrm{min}=0.1999$ temperature - 2.1292; $t=5.81$, df $=94, P<0.0001$, $\left.r^{2}=0.2639\right)$ with changing water temperatures. Across temperatures ranging from $13.1^{\circ}$ to $20.8^{\circ} \mathrm{C}$, larvae moved 2 times $/ 10 \mathrm{~min}(95 \%$ confidence interval $=1.3$ to $2.7, P<$ $0.0001)$ more for each $1^{\circ} \mathrm{C}$ increase in lake water temperature.

3.5. Movement Distances. During the short-duration (1-hour) movement trial conducted during the afternoon (between 13:30 and 14:30), total distances moved by individual Molanna larvae ranged from 4 to $251 \mathrm{~cm}$. Distances moved by larvae did not differ significantly $(t=0.42$, df $=13.31$ (adjusted for unequal sample variance), $P=0.683$ ) between high-density and low-density macrophyte beds. Overall, larvae moved an average of $35.2 \pm 49.0 \mathrm{~cm} /$ hour. However, movements were not uniform throughout the entire 1 hour of observations, with larvae moving significantly greater distances $\left(F_{3,51}=\right.$ 5.34, $P=0.003$ ) during the first $15 \mathrm{~min}$ (mean $\pm \mathrm{SD}: 18.2$ $\pm 22.5 \mathrm{~cm}$ ) than during any other period (all means $8 \mathrm{~cm}$ or less). This suggested a possible initial response of larvae to the presence of researchers, followed by acclimation and return to normal foraging activities. Consequently, we reanalyzed 


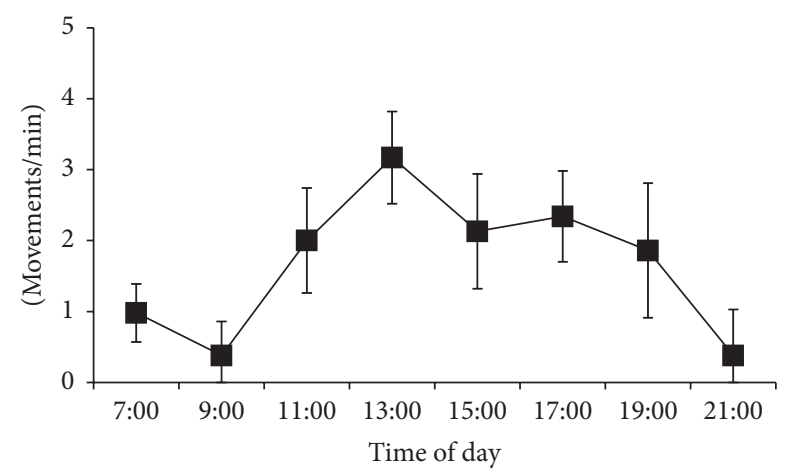

FIGURE 2: Number of feeding movements per minute displayed by Molanna uniophila larvae during different daylight time periods at Pratt Lake, Michigan, USA. Values are means and vertical lines represent $\pm 1 \mathrm{SD}$.

these data after discarding values collected for the first 15minute period. Distances moved by larvae again did not differ significantly $(t=0.67, \mathrm{df}=12.31$ (adjusted for unequal sample variance), $P=0.513$ ) between high-density and lowdensity macrophyte beds, and distances moved did not differ significantly $\left(F_{2,69}=0.09, P=0.914\right)$ among the three 15 minute time periods $(7.0 \pm 12.5 \mathrm{~cm}, 8.0 \pm 18.6 \mathrm{~cm}$, and $6.3 \pm$ $10.1 \mathrm{~cm}$, resp.). During the final 45 minutes of observation, larvae overall moved an average of $25.1 \pm 44.8 \mathrm{~cm}$ /hour.

During the two 12-hour trials examining distances moved by feeding Molanna larvae, weather conditions varied dramatically. During one trial, the weather was warm and sunny (water temperature range $=24.6$ to $27.8^{\circ} \mathrm{C}$ ), whereas during the other trial it was cool and rainy (water temperature range $=18.9$ to $20.6^{\circ} \mathrm{C}$ ). During the sunny day trial, larvae displayed no movement during only $8 \%$ of observations made, with all nonmovement occurring during the 08:00 and 10:00 observation periods. In contrast, larvae did not move during $33 \%$ of all observations made during the rainy day trial, with nonmovement appearing during every observation period. However, the distances moved by larvae during both days differed significantly among the time periods (2-hour periods during sunny day: Kruskal-Wallis $H=31.82$, $\mathrm{df}=6$, $P<0.001$; 1-hour periods during rainy day: $H=39.85$, $\mathrm{df}=11, P<0.0001)$.

On a sunny day, Molanna larvae moved only short distances $(<10 \mathrm{~cm} /$ hour$)$ during morning hours, but distances moved increased two- to fivefold during the afternoon before declining again during the evening (Figure 3). In contrast, during a day with continuous rainfall, larvae maintained relatively steady, short-distance movements throughout the entire daylight period (Figure 3). Despite these greatly reduced movements compared to those on the sunny day, larvae still displayed maximum distances moved during late afternoon, followed by reduced distances moved through the evening hours.

Distances moved by Molanna larvae while feeding in Pratt Lake were significantly correlated (distance moved/ hour $=2.9828$ temperature $-56.769 ; t=13.21, \mathrm{df}=288$, $\left.P<0.0001, r^{2}=0.3774\right)$ with changing water temperatures. Across temperatures ranging from $18.9^{\circ}$ to $27.8^{\circ} \mathrm{C}$, larvae

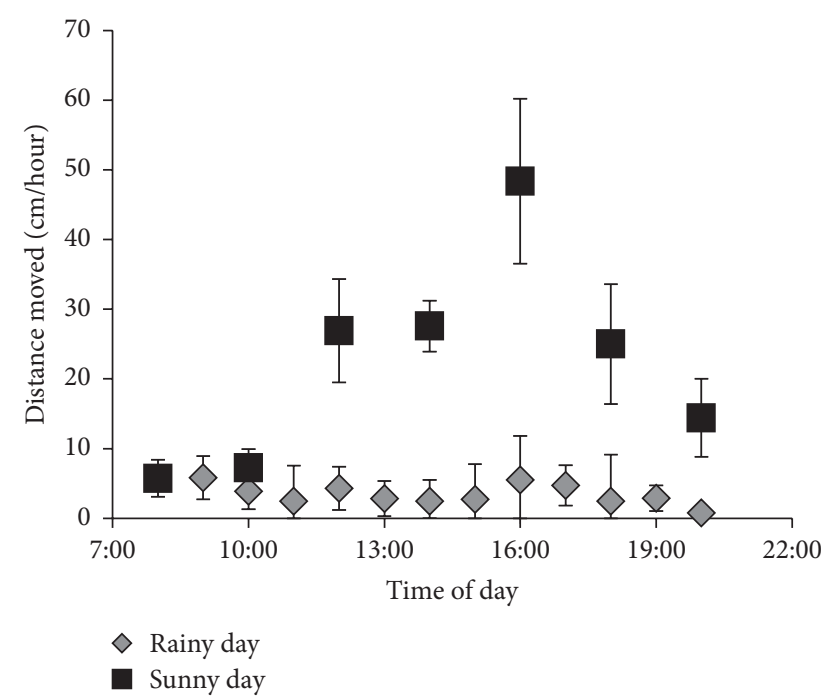

Figure 3: Distances moved by feeding Molanna uniophila larvae in Pratt Lake, Michigan, USA, during different daylight time periods on a rainy day and a sunny day. Values are means and vertical lines represent $\pm 1 \mathrm{SD}$.

moved $3 \mathrm{~cm} /$ hour $(95 \%$ confidence interval $=2.5$ to $3.4, P<$ $0.0001)$ more for each $1^{\circ} \mathrm{C}$ increase in lake water temperature.

\section{Discussion}

Observations of feeding M. uniophila larvae in Pratt Lake over the course of several field seasons produced three key findings. First, these larvae ingested a mixed diet of detritus, plants, algae, and small invertebrates while foraging in shallow, nearshore habitats, categorizing them as omnivorous collector/gatherers. Second, larvae maintained similar densities and moved at similar rates while feeding in both high-density and low-density macrophyte beds, indicating the ability to feed in this partial refuge from predators, but not using it to an advantage. Finally, both individual movements and distances moved by feeding larvae changed significantly during daylight hours, and these changes were correlated significantly with water temperature changes.

The feeding habits of Molanna larvae previously have been labeled as omnivorous, with diets including diatoms, algae, vascular plant tissue, rotifers, microcrustaceans, oligochaetes, insects, and detritus [10, 11, 21-23]. Molanna larvae in Pratt Lake consumed a majority of these food types, with diets dominated by amorphous detritus. Diets of Molanna larvae may become more diversified as they grow larger [21], but this was not examined for Pratt Lake specimens given the limited number and size range of larvae collected. Individual Molanna larvae in Pratt Lake consumed four to eight different food types (mean $=5.2$ food types/larva).

Densities and habitats of Molanna larvae in Pratt Lake were similar to previous reports for this taxon. Yearly mean densities of larvae in Pratt Lake (2.7 and 13.6 larvae $/ \mathrm{m}^{2}$ ) agreed with the 10.2 larvae $/ \mathrm{m}^{2}$ reported from Texas, USA [21]. Sand and gravel substrates appear to be the standard 
habitat used by Molanna larvae in all localities [10, 21-24]. However, larvae were never observed at depths $>35.5 \mathrm{~cm}$ in Pratt Lake, even though the species has been collected to a depth of $7 \mathrm{~m}$ and abundantly to $5 \mathrm{~m}$, in a lake in Wisconsin, USA [24]. Molanna larvae in Pratt Lake may be restricted to depths shallower than they are capable of utilizing, because bottom sediments in the lake transition from sand in waters $<0.5 \mathrm{~m}$ deep to silt and peat in waters $>0.5 \mathrm{~m}$.

Although many aquatic insect larvae confronted by potential predators alter the timing of their foraging activities $[6,18]$ and/or shift into more protected habitats for foraging $[12,13,25]$, caddisfly larvae in general demonstrate little response to the presence of predators $([12,13]$, but also see [26]). Caddisfly larvae without cases are readily consumed by predatory fish [27], but the presence of a case often results in caddisfly larvae being selected against by foraging predators [27]. We had suspected that Molanna larvae in Pratt Lake, despite the presence of their sand and gravel cases, would select foraging habitats that gave greater protection against predatory fish. Larvae were capable of feeding normally in high-density macrophyte beds, as judged by the distances moved while foraging, giving them the ability to take advantage of a refuge while foraging. However, densities of larvae were not different between high- and lowdensity macrophyte beds, suggesting lack of selection for high-density macrophyte beds [25].

We also observed that M. uniophila larvae in Pratt Lake foraged only during daylight hours, when sight-feeding predators were assumed to be most active. Many aquatic invertebrates adjust their foraging schedules to avoid actively feeding predators $[6,13,16,18]$. Apparently, M. uniophila larvae benefit from having "predator-resistant" cases that allow them to forage regardless of whether or not predators are present. Foraging during daylight hours would allow larvae to take advantage of slightly warmer water temperatures within the littoral zone of Pratt Lake, temperatures likely more conducive to efficient foraging $[17,28]$.

Foraging movements by Molanna larvae in Pratt Lake exhibited very strong periodicity, with low rates during morning and evening and the highest rates during the afternoon. Feeding periodicity is common among aquatic insect larvae (e.g., $[14,18]$ ), with peaks in activity variously attributed to predator avoidance behavior [18], hunger level [13], resource availability [26], and water temperature [17, 2830]. For Molanna larvae in Pratt Lake, we found strong, positive correlations between water temperature and both number of movements per time period and distance moved per time interval during foraging. The changing water temperatures in Pratt Lake were responsible for nearly $40 \%$ of the variability in movement rates and distances.

We suspect that food resource abundance and patchiness and wave action (none of which were assessed in our study) also may have influenced foraging movements of $M$. uniophila. Greater food resource abundance can reduce foraging movements as larvae spend more time feeding and less time moving $[14,31]$. In contrast, greater food resource patchiness can increase movements as larvae spend more time searching for food patches and less time feeding [14, 31]. Wave action in lakes, and the water movements that result from it in nearshore areas, also may influence foraging movements of larvae in a manner similar to how current velocities in streams affect feeding movements of invertebrates in those systems [4, 5, 31], reducing feeding movements as water velocities increase. With flattened sand and gravel cases that were 13 times heavier than themselves, Molanna larvae in Pratt Lake appeared to be well equipped to deal with water movements resulting from normal wave action, but larger waves may have reduced foraging movements.

\section{Conflict of Interests}

The authors declare that they have no conflict of interests regarding the publication of this paper.

\section{Acknowledgments}

The authors kindly acknowledge the Northrup family for providing lodging and access to the study site on Pratt Lake during the days of fieldwork. They also thank Dr. David Houghton for information on Molanna in Michigan and assistance with species identification.

\section{References}

[1] R. W. Merritt and K. W. Cummins, An Introduction to the Aquatic Insects of North America, Kendall/Hunt Publishing Company, Dubuque, Iowa, USA, 2nd edition, 1984.

[2] S. L. Kohler, "Search mechanism of a stream grazer in patchy environments: the role of food abundance," Oecologia, vol. 62, no. 2, pp. 209-218, 1984.

[3] N. L. Poff and J. V. Ward, "Heterogeneous currents and algal resources mediate in situ foraging activity of a mobile stream grazer," Oikos, vol. 65, no. 3, pp. 465-478, 1992.

[4] J. D. Olden, A. L. Hoffman, J. B. Monroe, and N. L. Poff, "Movement behavior and dynamics of an aquatic insect in a stream benthic landscape," Canadian Journal of Zoology, vol. 82, no. 7, pp. 1135-1146, 2004.

[5] A. L. Hoffman, J. D. Olden, J. B. Monroe, N. LeRoy Poff, T. Wellnitz, and J. A. Wiens, "Current velocity and habitat patchiness shape stream herbivore movement," Oikos, vol. 115, no. 2, pp. 358-368, 2006.

[6] A. Sih, "Foraging strategies and the avoidance of predation by an aquatic insect, Notonecta hoffmanni," Ecology, vol. 63, no. 3, pp. 786-796, 1982.

[7] B. L. Peckarsky, C. A. Cowan, M. A. Penton, and C. R. Anderson, "Sublethal consequences of stream-dwelling predatory stoneflies on mayfly growth and fecundity," Ecology, vol. 74, no. 6, pp. 1836-1846, 1993.

[8] T. A. Crowl and A. P. Covich, "Predator-induced life-history shifts in a freshwater snail," Science, vol. 247, no. 4945, pp. 949951, 1990.

[9] W. L. Hilsenhoff, "Rapid field assessment of organic pollution with family level biotic index," Journal of the North American Benthological Society, vol. 7, no. 1, pp. 65-68, 1988.

[10] G. LaFontaine, Caddisflies, Globe Pequot Press, Guilford, Conn, USA, 1981.

[11] G. B. Wiggins, Larvae of North American Caddisfly Genera (Trichoptera), University of Toronto Press, Toronto, Canada, 1996. 
[12] C. R. Ruetz III, R. M. Newman, and B. Vondracek, “Top-down control in a detritus-based food web: fish, shredders, and leaf breakdown," Oecologia, vol. 132, no. 2, pp. 307-315, 2002.

[13] S. L. Kohler and M. A. McPeek, "Predation risk and the foraging behavior of competing stream insects," Ecology, vol. 70, no. 6, pp. 1811-1825, 1989.

[14] D. D. Hart and V. H. Resh, "Movement patterns and foraging ecology of a stream caddisfly larva," Canadian Journal of Zoology, vol. 58, no. 6, pp. 1174-1185, 1980.

[15] T. L. Arsuffi and K. Suberkropp, "Selective feeding by stream caddisfly (Trichoptera) detritivores on leaves with fungalcolonized patches," Oikos, vol. 45, no. 1, pp. 50-58, 1985.

[16] T. M. Short and J. R. Holomuzki, "Indirect effects of fish on foraging behaviour and leaf processing by the isopod Lirceus fontinalis," Freshwater Biology, vol. 27, no. 1, pp. 91-97, 1992.

[17] D. A. McCullough, G. W. Minshall, and C. E. Cushing, "Bioenergetics of a stream 'collector' organism, Tricorythodes minutus (Insecta: Ephemeroptera)," Limnology and Oceanography, vol. 24, no. 1, pp. 45-58, 1979.

[18] J. H. Johnson, J. E. Ruggirello, and C. C. Nack, "Diel feeding periodicity of Ephemera simulans nymphs in summer and winter," Journal of Freshwater Ecology, vol. 27, no. 2, pp. 305308, 2012.

[19] D. C. Houghton, C. M. Brandin, and K. A. Brakel, "Analysis of the caddisflies (Trichoptera) of the Manistee River Watershed, Michigan," The Great Lakes Entomologist, vol. 44, no. 1-2, pp. 1$15,2011$.

[20] W. L. Hilsenhoff, "Aquatic insects of Wisconsin: with generic keys and notes on biology, ecology, and distribution," Technical Bulletin 89, Wisconsin Department of Natural Resources, Madison, Wis, USA, 1975.

[21] T. S. Gupta and K. W. Stewart, "Life history and case building behavior of Molanna tryphena (Trichoptera: Molannidae) in two east Texas spring-fed streams," Annals of the Entomological Society of America, vol. 93, no. 1, pp. 65-74, 2000.

[22] J. O. Solem, "Contributions to the knowledge of the larvae of the family Molannidae (Trichoptera)," Norsk Entomologisk Tidsskrift, vol. 17, no. 2, pp. 97-102, 1970.

[23] F. F. Sherberger and J. B. Wallace, "Larvae of the southwestern species of Molanna," Journal of the Kansas Entomological Society, vol. 44, pp. 217-224, 1971.

[24] R. A. Muttkowski, "The fauna of Lake Mendota: a qualitative and quantitative survey with special reference to the insects," Transactions of the Wisconsin Academy of Sciences, Arts, and Letters, vol. 19, no. 1, pp. 374-482, 1918, Notes from the Laboratory of the Wisconsin Geological and Natural History Survey. XI.

[25] J. C. Fisher, W. E. Kelso, and D. A. Rutherford, "Macrophyte mediated predation on hydrilla-dwelling macroinvertebrates," Fundamental and Applied Limnology, vol. 181, no. 1, pp. 25-38, 2012.

[26] N. Kuhara, S. Nakano, and H. Miyasaka, "Alterations in the grazing activities of cased caddisfly larvae in response to variations in predation risk and resource level," Ecological Research, vol. 16, no. 4, pp. 705-714, 2001.

[27] N. D. Mundahl, D. E. Mundahl, and E. C. Merten, "Success of slimy sculpin reintroductions in Minnesota trout streams: influence of feeding and diets," American Midland Naturalist, vol. 168, no. 1, pp. 162-183, 2012.

[28] M. C. Zimmerman and T. E. Wissing, "Effects of temperature on gut-loading and gut-clearing times of the burrowing mayfly,
Hexagenia limbata," Freshwater Biology, vol. 8, no. 3, pp. 269277, 1978.

[29] R. Dermott, "Ingestion rate of the burrowing mayfly Hexagenia limbata as determined with ${ }^{14}$ C," Hydrobiologia, vol. 83, no. 3, pp. 499-503, 1981.

[30] D. D. Hart, "Foraging and resource patchiness: field experiments with a grazing stream insect," Oikos, vol. 37, no. 1, pp. 46-52, 1981.

[31] J. D. Olden, "Critical threshold effects of benthiscape structure on stream herbivore movement," Philosophical Transactions of the Royal Society B: Biological Sciences, vol. 362, no. 1479, pp. 461-472, 2007. 

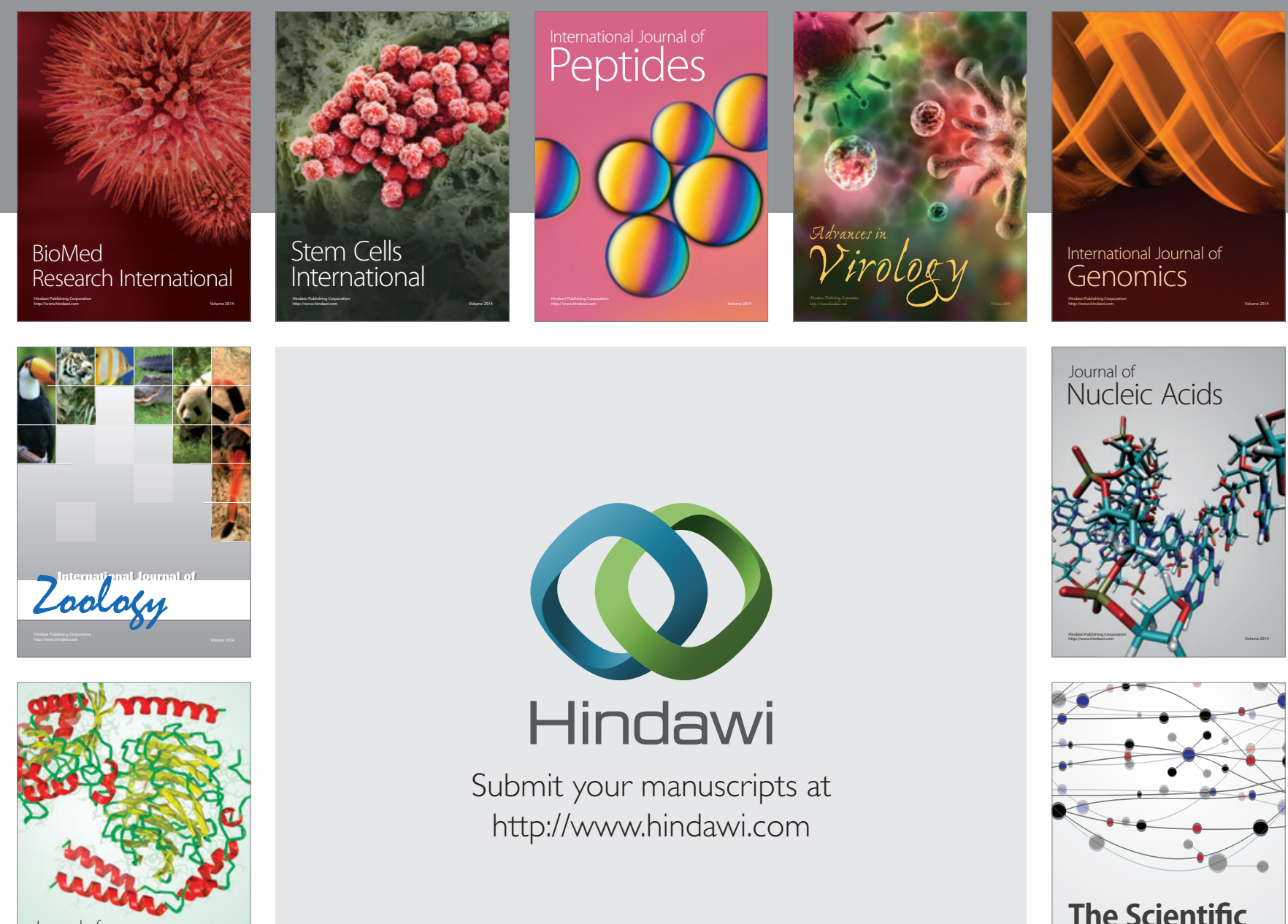

Submit your manuscripts at

http://www.hindawi.com

Journal of
Signal Transduction
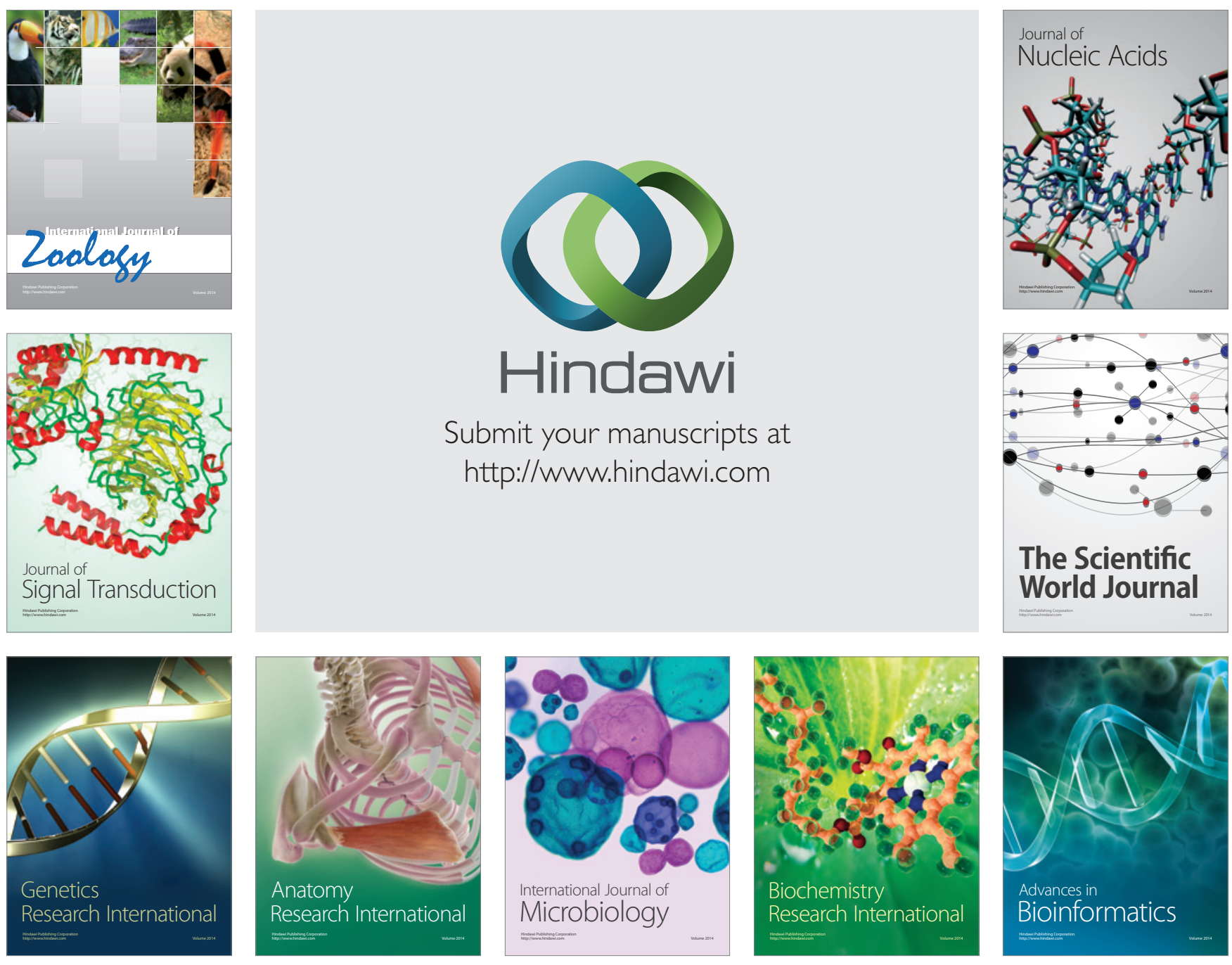

The Scientific World Journal
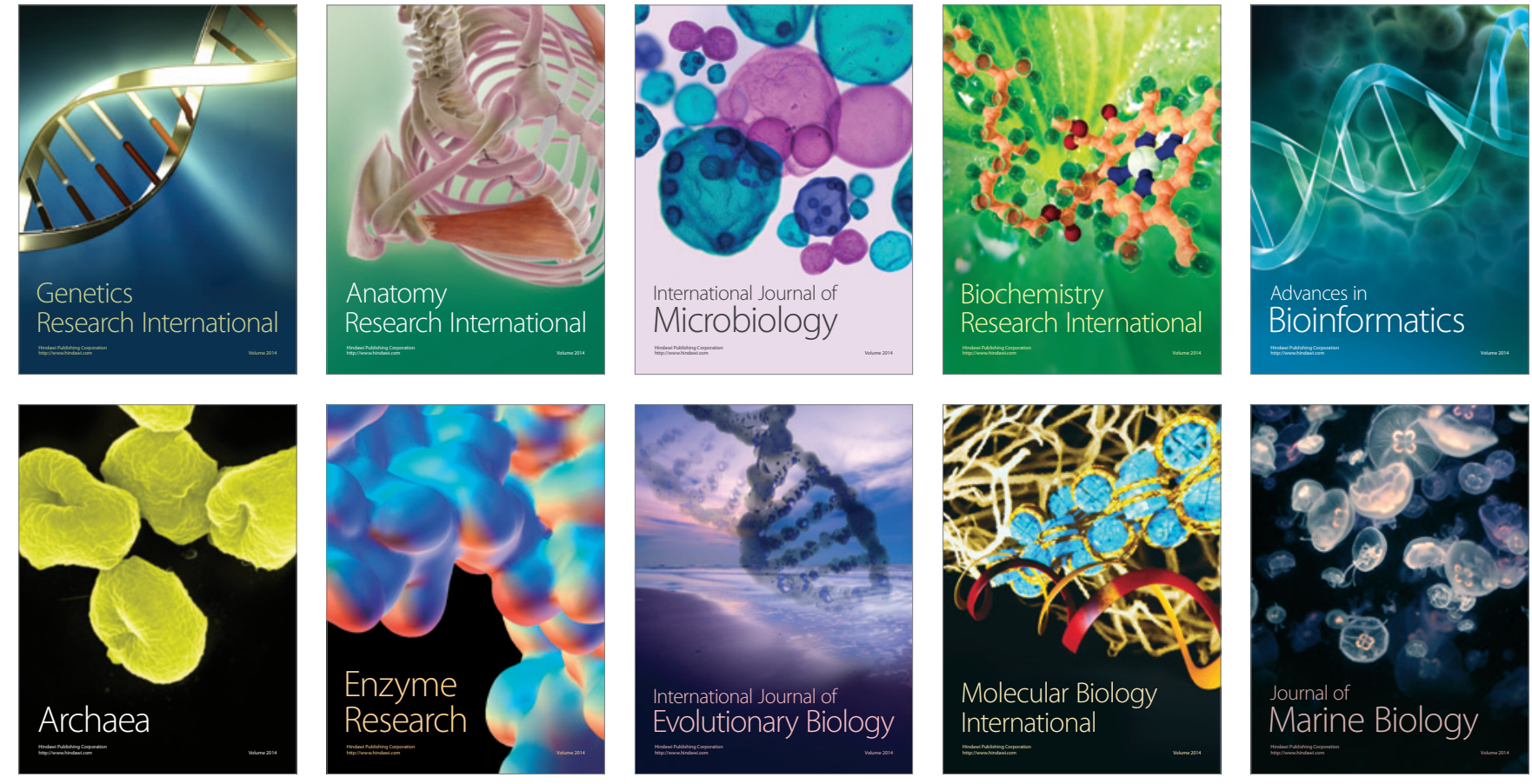